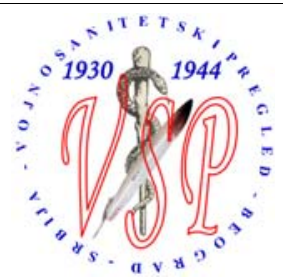

\title{
Cerebral palsy in preterm infants
}

\section{Cerebralna paraliza kod prevremeno rođene dece}

\author{
Čila Demeši Drljan*, Aleksandra Mikov*, Karmela Filipović ${ }^{\dagger}$, Snežana \\ Tomašević Todorović $c^{\ddagger}$, Aleksandar Knežević ${ }^{\ddagger}$, Rastislava Krasnik* \\ *Institute for Children and Youth Health Care of Vojvodina, ${ }^{\dagger}$ Special Hospital for \\ Rheumathic Diseases, ${ }^{\star}$ Clinical Center of Vojvodina, Faculty of Medicine, University of \\ Novi Sad, Novi Sad, Serbia
}

\begin{abstract}
Background/Aim. Cerebral palsy (CP) is one of the leading causes of neurological impairment in childhood. Preterm birth is a significant risk factor in the occurrence of CP. Clinical outcomes may include impairment of gross motor function and intellectual abilities, visual impairment and epilepsy. The aim of this study was to examine the relationships among gestational age, type of CP, functional ability and associated conditions. Methods. The sample size was 206 children with CP. The data were obtained from medical records and included gestational age at birth, clinical characteristics of CP and associated conditions. Clinical CP type was determined according to Surveillance of Cerebral Palsy in Europe (SCPE) and topographically. Gross motor function abilities were evaluated according to the Gross Motor Function Classification System (GMFCS). Results. More than half of the children with CP were born prematurely (54.4\%). Statistically significant difference was noted with respect to the distribution of various clinical types of CP in relation to gestational age $(p<0.001)$. In the group with spastic bilateral CP type, there is a greater proportion of children born preterm. Statistically significant difference was noted in the functional classification based on GMFCS in terms of gestational age $(p=0.049)$, children born at earlier gestational age are classified at a higher GMFCS level of functional limitation. The greatest percentage of children $(70.0 \%)$ affected by two or more associated conditions was found in the group that had extremely preterm birth, and that number declined with increasing maturity at birth. Epilepsy was more prevalent in children born at greater gestational age, and this difference in distribution was statistically significant $(p=0.032)$. Conclusion. The application of antenatal and postnatal protection of preterm children should be a significant component of the CP prevention strategy.
\end{abstract}

Key words:

Cerebral palsy; risk factors; infant, premature.

\section{Apstrakt}

Uvod/Cilj. Cerebralna paraliza (CP) jedan je od najčešćih uzroka nastanka neuroloških oštećenja u dečjem uzrastu. Prevremen porođaj je značajan faktor rizika od pojave CP. Kliničke posledice mogu biti oštećenje grube motoričke funkcije, intelektualnih sposobnosti, poremećaj vida i epilepsija. Cilj rada bio je da se istraži odnos između gestacijske starosti, oblika CP, funkcionalnih sposobnosti i pridruženih oboljenja. Metode. Uzorak se sastojao od ukupno 206 dece. Iz medicinske dokumentacije dobijeni su podaci o gestacijskoj starosti, kliničkim karakteristikama CP i pridruženim oboljenjima. Klinički tip CP određivan je prema preporuci Surveillance of Cerebral Palsy in Europe (SCPE) i topografski. Grube motoričke funkcije procenjivane su na osnovu istoimenog klasifikacionog sistema Gross Motor Function Classification System (GMFCS). Rezultati. Više od polovine dece sa CP prevremeno su rođena $(54,4 \%)$. Registrovana je statistički značajna razlika u distribuciji kliničkih tipova CP u odnosu na gestacijsku starost $(p<0,001)$; kod dece sa spastičnim bilateralnim tipom CP više su zastupljena prevemeno rođena deca. Utvrđena je statistički značajna razlika u funkcionalnoj klasifikaciji na osnovu GMFCS u odnosu na gestacijsku starost ( $p$ $=0,049)$; deca koja su manje gestacijske starosti imaju viši stepen prema GMFCS-u. Najveći procenat dece (70,0\%) koja imaju dva ili više pridruženih oboljenja utvrđen je kod izrazito prevremeno rođene dece i ovaj broj opada što je termin bliži normalnom terminu porođaja. Epilepsija je bila češća kod dece sa većom gestacijskom starosti i ova razlika u distribuciji bila je statistički značajna $(p=0,032)$. Zaključak. Primena antenatalne i postnatalne zaštite preterminski rođene dece trebalo bi da bude značajna komponenta strategije prevencije $C P$.

Ključne reči: paraliza, cerebralna; faktori rizika; nedonošče. 


\section{Introduction}

Cerebral palsy (CP) is one of the leading causes of neurological impairment in childhood ${ }^{1,2}$. Worldwide studies of the prevalence of this disorder indicate that it is much higher in developing countries and its incidence varies from 1.5 to 3 per 1,000 live births ${ }^{2,3}$. In some regions, CP prevalence has historically remained stable ${ }^{3}$. However, in most studies, changes were noted in the $\mathrm{CP}$ prevalence rates in indifferent risk groups, such as low birthweight infants (with body mass below 1,000 or $1,500 \mathrm{~g}$ ), or those born prematurely (before 32 weeks of gestation) ${ }^{4}$. Improved healthcare system can reduce $\mathrm{CP}$ prevalence by minimizing the effects of prenatal, perinatal and postnatal damage. On the other hand, by increasing survival rates of preterm infants, $\mathrm{CP}$ prevalence is likely to increase ${ }^{5}$.

Preterm birth is a significant risk factor in the occurrence of $\mathrm{CP}^{6,7}$. In preterm infants, secondary postnatal complications can develop, as a result of immaturity, or preexisting brain damage that occurred during prenatal or perinatal period ${ }^{6}$. Specific perinatal risk factors for CP in preterm infants are maternal-fetal infection, neonatal sepsis, and other serious conditions that can develop during the neonatal period. Brain damage resulting from periventricular hemorrhage, periventricular cystic leucomalacia and posthemorrhagic hydrocephalus in particular, are reliable predictors of future neurodevelopmental issues, and thus $\mathrm{CP}^{8}$. According to O'Callaghan et al. ${ }^{7}$, preterm birth, intrauterine fetal growth restriction, perinatal infection, and multiple births are the leading risk factors for developing $\mathrm{CP}$.

Prematurely born infants (preterm neonates) are babies born at gestational age below 37 weeks and can be classified into three groups, namely those born at 32-36, 28-31, and before 28 weeks of gestation ${ }^{9}$. Survival and neurological development of preterm children born after 32 weeks of gestation is similar to that of those carried to full term. However, the period from 20 to 32 weeks post-conception is characterized by rapid brain growth and development. Illness, undernourishment and infection during this period may compromise fetal neurodevelopmental progress, resulting in clinical outcomes that may include $\mathrm{CP}$, visual and hearing impairment, learning difficulties, as well as behavioral, psychological and social deficits ${ }^{8}$.

As preterm infants are at a greater risk of developing $\mathrm{CP}$, the aim of this study was to examine the relationships among gestational age, type of $\mathrm{CP}$, functional ability and associated conditions.

\section{Methods}

This qualitative study, clinical-epidemiological, classical type was conducted at the Clinic for Child Habilitation and Rehabilitation, the Institute for Child and Youth Healthcare of Vojvodina in Novi Sad. The study was approved by the Ethics Committee of the Institute and the Faculty of Medicine, University of Novi Sad. The analysis included all patients in whom the CP diagnosis had been established in 1990-2009 period, resulting in a sample of 206 children. A part of this comprehensive study was presented in this paper. Initially, medical history of all patients was reviewed in order to ascertain their gestational age at birth, as well as their CP clinical characteristics and associated conditions. Clinical CP type was determined according to Surveillance of Cerebral Palsy in Europe (SCPE) and topographically ${ }^{10}$. Based on the clinical presentation, gross motor function classification was performed, according to the five-level Gross Motor Function Classification System (GMFCS), whereby Level I indicates the highest functional ability, and Level $\mathrm{V}$ most severely limited motor function. For each of the five levels, the description of gross motor function is given for four age groups: before the 2nd birthday, between the 2nd and the 4th birthday, between the 4th and the 6th birthday, and between the 6 th and the 12 th birthday ${ }^{11}$. Data on associated conditions (mental deficit, epilepsy, visual impairment) was sourced from the reports provided by the child's neurologist, neuropediatrician, psychologist, speech therapist and ophthalmologist.

The collected data was input into a database specifically designed for the purpose of this study. The subsequent data analysis consisted of descriptive and inferential statistics. Attributive characteristics were presented through frequencies and percentages. Comparison of the observed and expected attributive characteristics frequencies was performed via $\chi^{2}$ test, whereas analysis of the correlation between two characteristics was conducted by applying Spearman correlation coefficient. All statistical analyses were performed using SPSS Statistics 17.0 computer software.

\section{Results}

Of the 145 children diagnosed with CP for whom gestational age at birth was documented, more than half were born prematurely (54.4\%). More specifically, 30.3\% were born at 32-36 weeks of gestation, $17.2 \%$ between 28 and 31 , and in $6.9 \%$ cases gestational period was shorter than 28 weeks. The distribution difference was found to be statistically significant $\left(\chi^{2}=48.572, p<0.001\right)($ Table 1$)$.

Table 1

Distribution of children with cerebral palsy (CP) by gestational age

\begin{tabular}{lcc}
\hline $\begin{array}{l}\text { Gestational age } \\
\text { (weeks) }\end{array}$ & $\begin{array}{c}\text { Total numbers of } \\
\text { patients, } \mathrm{n}(\%)\end{array}$ & $\begin{array}{c}\text { Patients with com- } \\
\text { plete data }(\%)\end{array}$ \\
\hline$<28$ & $10(4.9)$ & 6.9 \\
$28-31$ & $25(12.1)$ & 17.3 \\
$32-36$ & $44(21.4)$ & 30.3 \\
$>36$ & $66(32.0)$ & 45.5 \\
Total & $145(70.4)$ & 100.0 \\
No data & $61(29.6)$ & \\
\hline Total & $206(100.0)$ & \\
\hline
\end{tabular}

Of the 109 children classified as having spastic bilateral type of CP (of the 116 in the sample), more than half ( $n=64$; $58.7 \%)$ had diplegia, and the remaining $45(41.3 \%)$ quadriplegia. While nearly $1 / 3$ of the studied children had diplegia, spastic unilateral CP was somewhat less prevalent (affecting $29.5 \%$ of the children). In addition, while 
quadriplegia affected nearly quarter of the sample $(23.3 \%)$, $8.8 \%$ children were diagnosed with dyskinetic CP type, and $5.2 \%$ had ataxic CP (Table 2).

In children diagnosed with $\mathrm{CP}$, a statistically significant difference was noted with respect to the distribution of various clinical types of $\mathrm{CP}$ in relation to gestational age $\left(\chi^{2}=\right.$ $33.448, p<0.001)$. More than $2 / 3$ of the children diagnosed with spastic unilateral, dyskinetic and ataxic type of $\mathrm{CP}$ were born at full term $(71.8 \%, 69.2 \%$ and $66.7 \%$, respectively). In contrast, in the group with spastic bilateral CP type, there was a greater proportion of children born preterm, which constituted the majority of the group diagnosed with diplegia (85.4\%), whereas among those affected by quadriplegia, more than half $(51.6 \%)$ were prematurely born children. The data is presented in Table 3 .

A statistically significant difference was noted in the functional classification based on GMFCS in terms of gestational age $\left(\chi^{2}=15.541, p=0.049\right)$. As can be seen in Table 4 , in full-term children, Level I is most prevalent, accounting for more than a third of the sample (36.9\%), while fewer prematurely born children are classified as having this level of functionality $(14.3 \%$ of children born before 32 weeks of gestation, and $17.1 \%$ of those born at $32-36$ weeks of gesta- tion). The analysis of relationships between gestational age and GMFCS classification presented in Table 4 revealed negative correlation (nonparametric Spearman), which was not statistically significant $(p=0.751)$. This finding implies that children born at earlier gestational age are classified at a higher GMFCS level of functional limitation.

The majority of children delivered after 28 weeks of gestation have moderate or borderline mental deficit, which affects $41.2 \%$ of those born at 28-31 gestational age, $48.6 \%$ of those born at 32-36 weeks of gestation, and $40.0 \%$ full-term children. In the group born before 28 weeks of gestation, $75 \%$ of children have mental deficit, with equal proportion of those affected by the severe and moderate/borderline form $(37.5 \%)$. In line with the mental deficit, the distribution of the visual impairment severity in relation to gestational age is also evident. Severe visual impairment is most prevalent among children born before 28 weeks of gestation (20.0\%), while the mild/moderate form is more frequent among those born at 28-31 gestational age (28.0\%), those born at 32-36 gestational age $(22.7 \%)$, and full-term children (19.7\%). Epilepsy is more prevalent in children born at greater gestational age, and this difference in distribution (Table 5) is statistically significant $\left(\chi^{2}=8.795, p=0.032\right)$.

\section{Table 2}

Distribution of cerebral palsy (CP) types

\begin{tabular}{lcc}
\hline Clynical type of CP & $\begin{array}{c}\text { Total number of patients } \\
\mathrm{n}(\%)\end{array}$ & $\begin{array}{c}\text { Patients with complete data } \\
(\%)\end{array}$ \\
\hline Spastic unilateral & $57(27.7)$ & 29.5 \\
SB* diplegia & $64(31.1)$ & 33.2 \\
SB* quadriplegia & $45(21.8)$ & 23.3 \\
Dyskinetic & $17(8.3)$ & 8.8 \\
Ataxic & $10(4.9)$ & 5.2 \\
Total & $193(93.7)$ & 100.0 \\
No data & $13(6.3)$ & \\
\hline Total & $206(100.0)$ & \\
\hline
\end{tabular}

*SB - spastic bilateral.

Table 3

Distribution of cerebral palsy (CP) types by gestational age

\begin{tabular}{lccc}
\multicolumn{4}{c}{ Distribution of cerebral palsy (CP) types by gestational age } \\
\hline \multirow{2}{*}{ Clinical type of CP } & $\begin{array}{c}\text { Preterm birth } \\
\mathrm{n}(\%)\end{array}$ & $\begin{array}{c}\text { Term birth } \\
\mathrm{n}(\%)\end{array}$ & $\begin{array}{c}\text { Total } \\
\mathrm{n}(\%)\end{array}$ \\
\hline Spastic unilateral & $11(28.2)$ & $28(71.8)$ & $39(100.0)$ \\
SB diplegia & $41(85.4)$ & $7(14.6)$ & $48(100.0)$ \\
SB quadriplegia & $16(51.6)$ & $15(48.4)$ & $31(100.0)$ \\
Dyskinetic & $4(30.8)$ & $9(69.2)$ & $13(100.0)$ \\
Ataxic & $2(33.3)$ & $4(66.7)$ & $6(100.0)$ \\
\hline Total & $74(54.0)$ & $63(46.0)$ & $137(100.0)$ \\
\hline
\end{tabular}

SP - spastic bilateral; $\mathbf{n}$ - number of children.

Table 4

Distribution of Gross Motor Function Classification System (GMFCS) levels by gestational age

\begin{tabular}{lcccccc}
\hline Gestational age & \multicolumn{7}{c}{ GMFCS, n (\%) } \\
\cline { 2 - 7 } (weeks) & 1 & 2 & 3 & 4 & 5 & Total \\
\hline$<32$ & $5(14.3)$ & $11(31.4)$ & $9(25.7)$ & $6(17.1)$ & $4(11.4)$ & $35(100.0)$ \\
$32-36$ & $7(17.1)$ & $12(29.3)$ & $8(19.5)$ & $8(19.5)$ & $6(14.6)$ & $41(100.0)$ \\
$>36$ & $24(36.9)$ & $8(12.3)$ & $7(10.8)$ & $14(21.5)$ & $12(18.5)$ & $65(100.0)$ \\
\hline Total & $36(25.5)$ & $31(22.0)$ & $24(17.0)$ & $28(19.9)$ & $22) 15.6)$ & $141(100.0)$ \\
\hline
\end{tabular}

n - number of children. 
Table 5

Distribution of associated impairments/conditions by gestational age

\begin{tabular}{lccccc}
\hline \multirow{2}{*}{ Gestational age (weeks) } & \multicolumn{2}{c}{ Intellectual impairment } & \multicolumn{2}{c}{ Visual impairment } & \multirow{2}{*}{ Epilepsy } \\
\cline { 2 - 5 } & Severe & Moderate/mild & Severe & Moderate/mild & \\
\hline$<28$ & 37.5 & 37.5 & 20.0 & 10.0 & 10.0 \\
$28-31$ & 11.8 & 41.2 & 0.0 & 28.0 & 12.0 \\
$32-36$ & 25.7 & 48.6 & 9.1 & 22.7 & 27.3 \\
$>36$ & 18.0 & 40.0 & 0.0 & 19.7 & 39.4 \\
\hline Total & 20.9 & 42.7 & 4.1 & 21.4 & 29.0 \\
\hline
\end{tabular}

The results are given as percentage of children.

The greatest percentage of children (70.0\%) affected by two or more concomitant conditions is found in the group that had extremely preterm birth $(<28$ gestational weeks $)$, and this number declines with increasing maturity at birth. Similarly, the number of children without any concomitant conditions increases with gestational age (from $10 \%$ for extremely preterm children to $25.8 \%$ for those born at full term). However, the differences in the total number of concomitant conditions in relation to gestational age were not statistically significant $(p=0.200)$. The data is shown in Table 6. affected by the harmful noxa prenatally, which partly explains the relatively high CP prevalence in the extremely premature neonates ${ }^{17}$.

Diplegia is the dominant CP subtype, and in more than $50 \%$ of cases, it occurs in preterm infants ${ }^{5,17}$. In the present study, $33.2 \%$ of children included in the sample had diplegia, of whom $55.4 \%$ were born preterm, and $80 \%$ had low birthweight. Variations in the percentage participation of the diplegic CP form reported in the extant literature (35-39.8\%) can potentially be explained by the variable prevalence of preterm neonates in the total population of children with $\mathrm{CP}^{5,17}$.

Table 6

\begin{tabular}{lcccc}
\multicolumn{5}{c}{ Number of associated impairments by gestational age } \\
\hline $\begin{array}{l}\text { Gestational age } \\
\text { (weeks) }\end{array}$ & 0 & Associated impairments, $\mathrm{n}(\%)$ & Total \\
\hline$<28$ & $1(10.0)$ & 1 & 2 or more & $10(100.0)$ \\
$28-31$ & $3(12.0)$ & $11(44.0)$ & $11(40.0)$ & $25(100.0)$ \\
$32-36$ & $5(11.4)$ & $12(27.3)$ & $27(61.4)$ & $44(100.0)$ \\
$>36$ & $17(25.8)$ & $16(24.2)$ & $33(50.0)$ & $66(100.0)$ \\
\hline Total & $26(17.9)$ & $41(28.3)$ & $78(53.8)$ & $145(100.0)$ \\
\hline n- number of children. & & &
\end{tabular}

\section{Discussion}

Preterm birth is recognized as the key risk factor for developing $\mathrm{CP}^{7,12,13}$, in particular if it occurs prior to 32 weeks of gestation ${ }^{13}$. A meta analysis of 26 studies revealed the CP prevalence of $14.6 \%$ for children born at 22-27 gestational age, $6.2 \%$ for those born at $28-31,0.7 \%$ for those born at $32-36$ weeks of gestation, and $0.1 \%$ for full-term children ${ }^{14}$. Our results indicate that about half of the children affected by $\mathrm{CP}$ were born preterm, of whom $17 \%$ were delivered at $28-32$ weeks of gestation and $7 \%$ before 28 weeks of gestation. Preterm children with CP have periventricular white matter damage. The damage to posterior thalamic region is most prominent, which correlates with reduced sensory-motor ability at the contralateral side. In rare cases, descendent corticospinal tract is also affected ${ }^{15}$. The presence of prenatal infection contributes to the increased risk of $\mathrm{CP}$ in prematurely born children. One of the mechanisms responsible for its development is neurotoxicity of cytokines that initiate chain reaction, resulting in apoptosis of various brain cells, predominantly oligodendrocytes, which are responsible for myelination ${ }^{16}$. Advancements in neonatal intensive care have contributed to the reduction in prenatal and neonatal death rates over time; however, most children are
Our study findings indicate that quadriplegia is present in $23.3 \%$ children, while other authors reported somewhat lower values, ranging from $15 \%$ to $20 \%{ }^{18}$. This disparity may be due to the different treatment provided to neonates in the intensive care unit, therapies offered, as well as differences in prenatal care. According to our findings, quadriplegia is equally prevalent among full-term and preterm children in our sample. One group of authors reported that the dyskinetic form was present in $11-13 \%$ of children with $\mathrm{CP}^{2,19}$. In our sample, this percentage is somewhat lower (8.3\%), most likely due to the recently adopted practice of making the diagnosis based on the dominant symptom. In that case, children with the dyskinetic form of CP that also present with spasticity are classified as having spastic bilateral CP type ${ }^{2}$. In the study conducted by Serdaroglu et al. ${ }^{5}$, dyskinetic form of CP was found in $6.4 \%$ children. Our results indicate that the dyskinetic form primarily occurred in full-term children born with normal body mass. Ataxic CP form is least prevalent and occurs in $4.7-5.9 \%$ cases, which is in accordance with our findings $(4.9 \%){ }^{5,17,18}$.

Our findings revealed a statistically significant difference in the functional ability distribution, as determined according to GMFCS, in relation to gestational age. Level I was most prevalent among the full-term children, while 
prematurely born children were assigned higher GMFCS levels. According to numerous studies, children with hemiplegia, most of whom were born at full term, predominantly exhibit Level I functional ability ${ }^{20-22}$. In our study, slightly more than $50 \%$ of children were born preterm. According to several authors, the most severe form of CP is linked to the higher GMFCS levels, predominantly Level $\mathrm{V}^{23-25}$.

Our findings indicate that children born before 28 weeks of gestation presented with the greatest number of concomitant conditions, which is in line with the results reported in the literature ${ }^{19,26,27}$. Marlow et al. ${ }^{27}$ reported that cognitive and neurological impairments were most prevalent among children born before 26 weeks of gestation. In the study conducted by Laptook et al. ${ }^{26}$, nearly $30 \%$ of children born on the average at 26 weeks of gestation, with normal brain ultrasound findings, were subsequently diagnosed with $\mathrm{CP}$ or had learning difficulties. Mongan et al. ${ }^{28}$ reported that, in their study, $56 \%$ of the children with $\mathrm{CP}$ had intellectual impairment, which was severe in $35 \%$ of those cases. The authors also concluded that the probability of children of normal birthweight developing intellectual impairment was twice as high as that found for those with low birthweight. Our findings indicate that severe mental deficit was most prevalent in children born before 28 weeks of gestation. When discussing the developmental prognosis with the parents, it is necessary to consider the associated cognitive impairment, as severe intellectual disability can significantly reduce the likelihood of the child learning to walk ${ }^{29}$. Among children with $\mathrm{CP}$, nonverbal learning deficits, accompanied by limited visual-spatial ability, are common ${ }^{30}$. According to the literature reports, $22-41 \%$ children with $\mathrm{CP}$ have epilepsy, the prevalence of which varies across subtypes $28,30,31$. Our findings indicate that epilepsy mostly occurred in children born at or close to full term. On the other hand, greater number of prematurely born children suffered from retinopathy, cortical visual impairment and strabismus, compared to the children with $\mathrm{CP}$ born at full term ${ }^{32}$. In our study, severe visual impairment was most prevalent among children born before 28 weeks of gestation $(20 \%)$. In prematurely born children, while compromised sight is mostly due to the retinopathy of prematurity (ROP), it can also result from cortical damage. ROP typically occurs in children born before 32 weeks of gestation and its incidence and severity are inversely proportional to gestational age ${ }^{8}$.

\section{Conclusion}

Among the prematurely born children included in this study, bilateral spastic CP type and higher GMFCS level of functional limitation were most prevalent. Children born before 28 weeks of gestation had the greatest number of associated conditions, as well as greatest prevalence of more severe cognitive and visual impairment. Providing antenatal and postnatal care to preterm infants should certainly be an important component of the CP prevention strategy.

\section{Acknowledgements}

The research was supported by the Grant of the Ministry of Education, Science and Technological Development of the Republic of Serbia, project No 41012 and 44008.

\section{R E F E R E N C E S}

1. Stelmach T, Pisarev H, Talvik T. Ante- and perinatal factors for cerebral palsy: case-control study in Estonia. J Child Neurol 2005; 20(8): 654-60.

2. Himmelmann K, Hagberg G, Wiklund LM, Eek, MN, Uvebrant P. Dyskinetic cerebral palsy: a population-based study of children born between 1991 and 1998. Dev Med Child Neurol 2007; 49(4): 246-51.

3. Winter S, Autry A, Boyle C, Yeargin-Allsopp M. Trends in the prevalence of cerebral palsy in a population-based study. Pediatrics 2002; 110(6): 1220-5.

4. Pakula AT, Van Braun NK, Yeargin-Allsopp M. Cerebral palsy: classification and epidemiology. Phys Med Rehabil Clin N Am 2009; 20(3): 425-52.

5. Serdaroğlu A, Cansu A, Orkan S, Tezcan S. Prevalence of cerebral palsy in Turkish children between the ages of 2 and 16 years. Dev Med Child Neurol 2006; 48(6): 413-6.

6. Dolk H, Parkes J, Hill N. Trends in the prevalence of cerebral palsy in Northern Ireland, 1981-1997. Dev Med Child Neurol 2006; 48(6): 406-12.

7. O'Callaghan ME, MacLennan AH, Gibson CS, McMichael GL, Haan $E A$, Broadbent JL, et al. Epidemiologic associations with cerebral palsy. Obstet Gynecol 2011; 118(3): 576-82.

8. Colvin M, McGuire W, Fowlie PW. Neurodevelopmental outcomes after preterm birth. BMJ 2004; 329(7479): 1390-3.

9. Venkateswaran S, Shevell MI. Comorbidities and clinical determinants of outcome in children with spastic quadriplegic cerebral palsy. Dev Med Child Neurol 2008; 50(3): 216-22.
10. Bax M, Goldstein M, Rosenbaum P, Leviton A, Paneth N, Dan B, et al. Proposed definition and classification of cerebral palsy, April 2005. Dev Med Child Neurol 2005; 47(8): 571-6.

11. Palisano RJ, Cameron D, Rosenbaum PL, Walter SD, Russell D. Stability of the Gross Motor Function Classification System. Dev Med Child Neurol 2006; 48(6): 424-8.

12. Bonellie SR, Currie D, Chalmers J. Comparison of risk factors for cerebral palsy in twins and singletons. Dev Med Child Neurol 2005; 47(9): 587-91.

13. Thorngren-Jerneck $K$, Herbst A. Perinatal factors associated with cerebral palsy in children born in Sweden. Obstet Gynecol 2006; 108(6): 1499-505.

14. Himpens E, van den Broeck C, Oostra A, Calders P, V anhaesebrouck $P$. Prevalence, type, distribution, and severity of cerebral palsy in relation to gestational age: a meta-analytic review. Dev Med Child Neurol 2008; 50(5): 334-40.

15. Hoon AH, Stashinko EE, Nagae LM, Lin DD, Keller J, Bastian A, et al. Sensory and motor deficits in children with cerebral palsy born preterm correlate with diffusion tensor imaging abnormalities in thalamocortical pathways. Dev Med Child Neurol 2009; 51(9): 697-704.

16. Marret S, Zupan V, Gressens P, Lagercrantz. H, Evrard P. Periventricular leukomalacia. I. Histological and pathophysiological aspects. Arch Pediatr 1998; 5(5): 525-37.

17. Sigurdardóttir S, Thórkelsson T, Halldórsdóttir M, Thorarensen $O$, Vik $T$. Trends in prevalence and characteristics of cerebral 
palsy among Icelandic children born 1990 to 2003. Dev Med Child Neurol 2009; 51(5): 356-63.

18. Andersen GL, Irgens LM, Haagaas I, Skranes JS, Meberg AE, Vik T. Cerebral palsy in Norway: prevalence, subtypes and severity. Eur J Paediatr Neurol 2008; 12(1): 4-13.

19. Himmelman K. Cerebral Palsy in Western SwedenEpidemiology and Function. Sweden: The Sahlgrenska Academy at Goteborg University; 2006.

20. Beckung E, Carlsson G, Carlsdotter S, Uvebrant P. The natural history of gross motor development in children with cerebral palsy aged 1 to 15 years. Dev Med Child Neurol 2007; 49(10): $751-6$.

21. Voorman JM, Dallmeijer AJ, Knol DL, Lankhorst GJ, Becher JG. Prospective longitudinal study of gross motor function in children with cerebral palsy. Arch Phys Med Rehabil 2007; 88(7): $871-6$.

22. Caram LH, Funayama CA, Spina CI, Giuliani Ld, de Pina NJM. Investigation of neurodevelopment delay etiology: resources and challenges. Arq Neuropsiquiatr 2006; 64(2B): 466-72.

23. Pfeifer LI, Silva DB, Funayama CA, Santos JL. Classification of cerebral palsy: association between gender, age, motor type, topography and Gross Motor Function. Arq Neuropsiquiatr 2009; 67(4): 1057-61.

24. Himmelmann K, Beckung E, Hagberg G, Uvebrant P. Gross and fine motor function and accompanying impairments in cerebral palsy. Dev Med Child Neurol 2006; 48(6): 417-23.

25. Howard J, Soo B, Graham KH, Boyd RN, Reid S, Lanigan A, et al. Cerebral palsy in Victoria: Motor types, topography and gross motor function. J Paediatr Child Health 2005; 41(9-10): 479-83.

26. Laptook. AR, O'Shea MT, Shankaran S, Bhaskar B. Adverse neurodevelopmental outcomes among extremely low birth weight infants with a normal head ultrasound: prevalence and antecedents. Pediatrics 2005; 115(3): 673-80.

27. Marlow N, Wolke D, Bracewell MA, Samara M. Neurologic and developmental disability at six years of age after extremely preterm birth. N Engl J Med 2005; 352(1): 9-19.

28. Mongan D, Dunne K, O'Nuallain S, Gaffney G. Prevalence of cerebral palsy in the West of Ireland 1990-1999. Dev Med Child Neurol 2006; 48(11): 892-5.

29. Beckung E, Hagberg G, Uldall P, Cans C. Surveillance of Cerebral Palsy in Europe. Probability of walking in children with cerebral palsy in Europe. Pediatrics 2008; 121(1): e187-92.

30. Sigurdardottir S, Eiriksdottir A, Gunnarsdottir E, Meintema M, Arnadottir $U, V i k, T$. Cognitive profile in young Icelandic children with cerebral palsy. Dev Med Child Neurol 2008; 50(5): 357-62.

31. Odding E, Roebroeck ME, Stam HJ. The epidemiology of cerebral palsy: incidence, impairments and risk factors. Disabil Rehabil 2006; 28(4): 183-91.

32. Pennefather PM, Tin $W$. Ocular abnormalities associated with cerebral palsy after preterm birth. Eye (Lond) 2000; 14(Pt 1): $78-81$

Received on March 21, 2014

Revised on December 21, 2014.

Accepted on March 10, 2015.

Online First February, 2016. 